\title{
Robert Hertz's seminal essay and mortuary rites in the Pacific region
}

\section{Eric Venbrux}

\section{(2) OpenEdition \\ 12 Journals}

Electronic version

URL: http://journals.openedition.org/jso/712

DOI: $10.4000 /$ jso. 712

ISSN: $1760-7256$

Publisher

Société des océanistes

\section{Printed version}

Date of publication: 1 June 2007

Number of pages: 5-10

ISBN: 978-2-85430-010-9

ISSN: 0300-953x

\section{Electronic reference}

Eric Venbrux, "Robert Hertz's seminal essay and mortuary rites in the Pacific region », Journal de la Société des Océanistes [Online], 124 | Année 2007-1, Online since 02 July 2008, connection on 10 December 2020. URL : http://journals.openedition.org/jso/712 ; DOI : https://doi.org/10.4000/jso.712

\section{(c) (i) $\odot$}

Journal de la société des océanistes est mis à disposition selon les termes de la Licence Creative Commons Attribution - Pas d'Utilisation Commerciale - Pas de Modification 4.0 International. 


\section{Robert Hertz's seminal essay and mortuary rites in the Pacific region}

par

Eric VENBRUX*

This special issue emerged from a session, entitled 'Spiritual material: Objects and change in mortuary ritual,' that Pierre Lemonnier and I organized at the conference of the European Society for Oceanists (ESfO) in Marseille in June 2005. In this session we explored the link between the spiritual and the material in mortuary ritual in the Pacific region. Inspired by the French anthropologist Robert Hertz (18811915), who in his 1907 essay on secondary funerals demonstrated a correspondence between the decay of the corpse and the fate of the soul, we focused on artifacts other than the human body. We returned to the basic tenet of his theory that "to make a material object or living being pass from this world to the next, to free or create the soul, it must be destroyed. [...] As the visible object vanishes it is reconstructed in the beyond, transformed to a greater or lesser degree" (Hertz, 1960: 46). There are cases in which the deceased's intimate possessions are destroyed, but also instances in which objects of the dead are kept as relics or heirlooms. Why?

In line with Hertz's argument we might make a distinction here between flesh-type and bonetype of objects. The latter seem to mediate the relationship between the living and the dead. They remain intact like the corpse's dry bones. The other objects, being destroyed, resemble the vanishing flesh, seemingly considered one with the imagery of the physical body or inseparable from the deceased in one way or another. The connection between the spiritual (as expressed in verbal formulations or otherwise) and the material was further examined by looking at change in mortuary ritual: do changes in people's notions of an otherworldly spiritual existence coincide with changes in the material aspects of mortuary ritual? And finally, why is it that people tend to adhere most strongly to their mortuary rituals, while paradoxically at an early stage introduced goods often become items of mortuary exchange?

Throughout the session there were lively discussions that showed the actuality of Hertz's insights. A vivid demonstration of a bone-type of object was given at the end of the conference when a Tikopian fish-hook ornament associated with Sir Raymond Firth was handed down to Maurice Godelier, who in turn contemplated about the passing on of this heirloom of the anthropological tribe. Here, however, we consider Hertz's 1907 essay an "enigmatic gift," still valuable in the twenty-first century.

The issue commemorates the centennial of the publication of Hertz's seminal essay 'Contribution à une Étude sur la Représentation Collective de la Mort.' The essay first appeared in L'Année sociologique (vol. 10, pp. 48-137) in 1907. Translated into English by Rodney and Claudia Needham - and entitled 'A Contribution to the Study of the Collective Representation of Death,' it came out together with another essay in the book Death and the Right Hand in 1960. In the same year Arnold van Gennep's 1909 book Les Rites de Passage was published in an English translation. Both works would have an impact on the understanding of ritual in the Englishspeaking world. Hertz's essay already contained the idea of rites of passage, and Hertz thus pre-

* Radboud University Nijmegen, The Netherlands, E.Venbrux@maw.ru.nl 
ceeded Van Gennep in recognizing the structural commonalities of the rituals concerned. The tripartite structure, promoted by Van Gennep, might even be found in every ritual as Van Baal (1971: 138) has argued. Hertz differs from Van Gennep in considering a particular type of ritual, secondary burial, in a particular cultural area. Hertz also pays greater attention to the emotional impact of a death in relation to the deceased's social position and to the survivors' work of mourning.

As Oceanists we of course focus on societies in the South Pacific rather than on the Dayak peoples of Kalimantan (Borneo), Hertz's prime example. Yet Hertz did make references to the literature on mortuary practices and rites in Melanesia, Polynesia and Australia. While referring to Codrington, for example, he states that in "several Melanesian islands" the decay of the corpse is speeded up in order to strengthen the soul (Hertz, 1960: 47, 128 n118). It does help Hertz to make a very important point: "Death is fully consummated only when decomposition has ended; only then does the deceased cease to belong to this world so as to enter another life" (1960: 47). What is more, the shift in regional focus allows us to toss with his ideas, examine their applicability cross-culturally in a neighbouring geographical area, offering sufficient diversity for the purposes of comparison. Moreover, while inspired by Hertz's thesis, particularly the condition of the corpse as a metaphor for the fate of the soul or the dead person's "non-mortal components," we want to go beyond that: we ask about the deceased's personal belongings. Like Hallam and Hockey, we are thus interested in the "practices that engage bodies and their familiar material 'extensions' (for example, clothing)" (2001: 197). If indeed "funerary behaviour and beliefs around the world read like an extended discussion of the notion of the person" (Barley, 1995: 27) we might ask to what extent the deceased's intimate possessions are part of the concept of the person. More in general, we seek to extend Hertz's argument not only to the material objects associated with the dead but also to ritual change. According to Hertz the decay of the corpse is associated to the fate of the soul of the deceased (and the survivors' period of mourning). Following this line of reasoning changes in the treatment of the corpse and related material objects should have consequences for people's perspective on death. Alternatively, it suggests that changes in ideas about death (for example, due to conversion) might be reflected in the adaptation of ritual practices, that is, the material aspects of funerary ritual. Hertz's classic and seminal essay thus suggests that changes in ideas about death reflect in the adaptation of ritual practices, and vice versa.

\section{Continued relevance}

Recent anthropological studies of death - ranging from Greece (Seremetakis, 1991) to Japan (Suzuki, 2000) - continue to support the hypothesis first advanced by Hertz. His essay forms an important source of inspiration even after one hunderd years. "It now stands as a basic historical and key theoretical reference point for sociological work on death," according to Davies (2000: 97). Palgi and Abramovitch (1984: 388) call the essay "one of the most original analyses pertaining to death" that "is still one of the most cited and seminal works in the field." And Robben, introducing his recent anthology of death studies, notes that Hertz's essay “endures as the single most influential text in the anthropology of death" (2004: 9). Parkin, however, would not make such a strong claim concerning Hertz's impact. He remarks, in addition, that "only a few have examined his thoughts at all critically or sought to take them further" (1997: 87). We agree with Robert Parkin that Hertz's essay contains ideas that may be further explored.

As Metcalf and Huntington (1991: 36) point out, "the symbolic aspects of Hertz's argument have been passed over." They further remark that "The complex issues raised by the death essay have yet to be discussed." To this end they provide an invaluable contribution. Besides elaborating on symbolism in mortuary rites, they seek to clarify their underlying structure. Especially what Hertz termed "the intermediary period" is of interest, because in this liminal phase corpse, soul and mourners undergo a parallel transition. Thereby the interrelatedness of these three aspects of the pattern is demonstrated, while every side in this triangular model provides a distinctive explanation. Metcalf and Huntington (1991: 83) summarize the three levels of explanation in Hertz's essay in the following figure.

The final ceremony or secondary burial marks the accomplishment of bodily decay as shown by the dry bones, the journey of the soul to the other world, and the work of mourning. As Hertz puts it, "death as a social phenomenon consists in a dual and painful process of mental disintegration and synthesis" (1960: 86). Thomas Maschio (1998: 56) points out that in this process an ossification or fixation of people's 


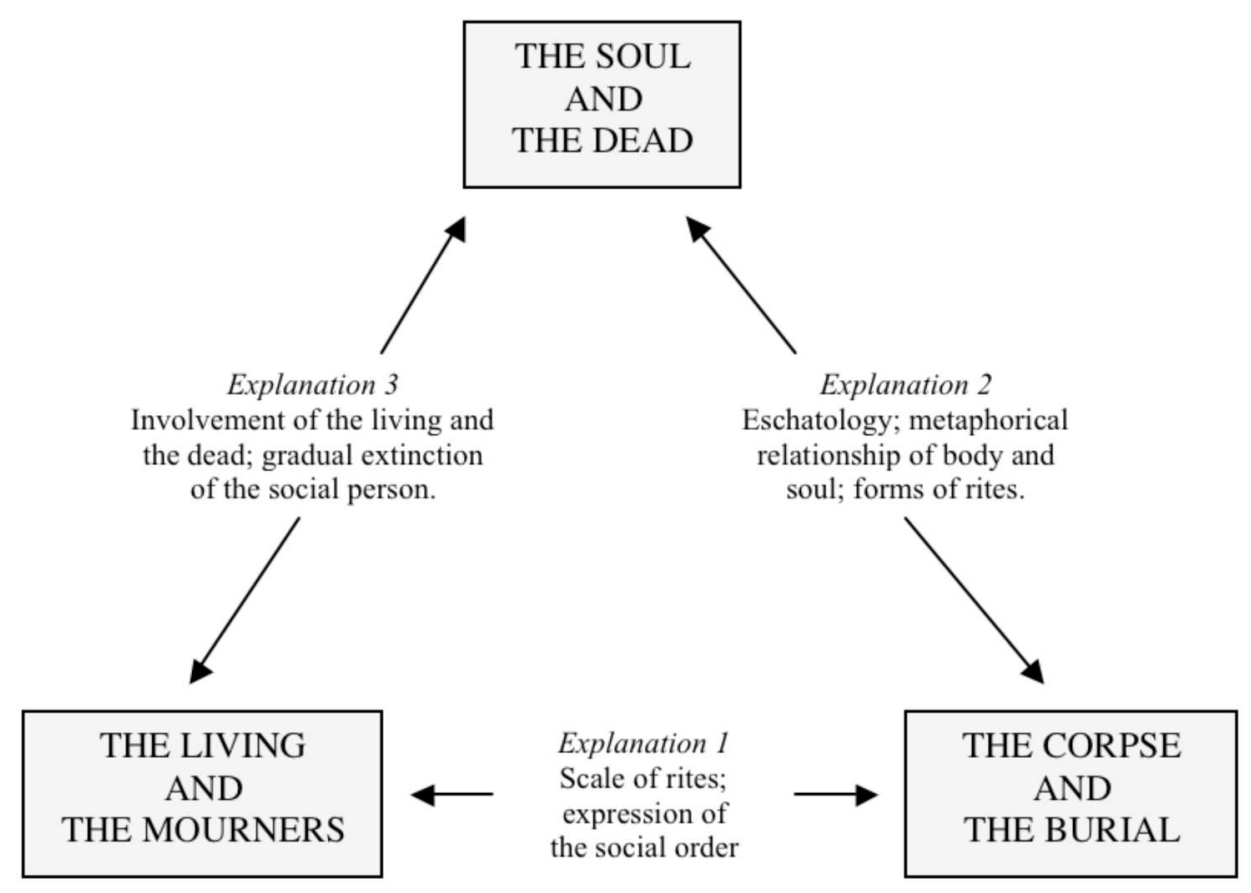

Schematic diagram of Hertz's arguments (Metcalf \& Huntington, 1991, p. 83)

memory of the deceased takes place as well. In showing how religious ideas are expressed in materialized form, Hertz appears to have been way ahead of current scholarship concentrating on so-called material religion.

Bloch and Parry (1982) have also taken inspiration from Hertz, but are more concerned with the issue of fertility in death rites. More names of scholars (e.g., Metcalf, 1982) could be mentioned, it should be clear however that Hertz's essay was a major achievement. "Here, for the first time, we are presented with a well formed sociological and theoretical understanding of funerary rites," says Davies (2000: 98). EvansPritchard (1981: 172) considers the works by Hertz "a representative example of the culmination of two centuries of sociological thought in France." He recognizes Hertz as a brilliant student of Durkheim. But Evans-Pritchard also points out what he regards as shortcomings of the Durkheimian school, the master and his gifted pupil alike. In the introduction to the English translation of Hertz's essays on mortuary ritual and the preeminence of the right hand, EvansPritchard makes the following three points of criticism. Both the "dichotomy of sacred and profane" and the so-called "collective consciousness" are "vague and ill-defined" in his view. Thirdly, he criticizes the disregard of negative cases, including the explaining away of contradictory developments (Evans-Pritchard, 1960: 12, 21-22; but see Needham, 1979: 296). Evans-Pritchard, however, also expresses his appreciation for the skilful use of the comparative method. Furthermore, although not in full agreement with Hertz, he stresses the latter's theoretical contribution. Hertz provides "stimulating hypotheses which can [...] be put to the test by further research" (Evans-Pritchard, 1960: 21). It is our contention that such further research, preferably in another but related cultural region, will still be productive and perhaps unexpectedly revealing.

\section{Comparison}

Hertz showed the way in his comparative approach, which was restricted to a clearly circumscribed cultural space or region. In 1935 Dutch anthropologist J.P.B. de Josselin de Jong introduced the notion of "a field for ethnological study." He did so with regard to the Malay Archipelago, while his students Lex van der Leeden and Jan Pouwer applied it to New Guinea. Such an area is described as "a limited part of the earth's surface with a population whose culture as a whole appears sufficiently homogenous and distinctive to form a special object of study for ethnology, and which at the same time 
appears to exhibit enough local variations for an internal comparative investigation to be fruitfully possible" (de Josselin de Jong cited in Pouwer, 1961: 1). Hertz concentrated on what, following de Josselin de Jong, might be termed a field for ethnological study.

The advantage of this procedure is spelled out by Evans-Pritchard (1981): In spite of the variability in the disposal of the corpse Hertz demonstrated that in the different settings the facts were interrelated and in all of them the mortuary practices had a similar function and goal. Next the findings could be compared with data from other regions in order to see whether these did hold water there as well or not (and had to be modified). To this end, as mentioned, Hertz also drew on the contemporary literature on mortuary rites in Oceania.

This does not mean, however, that in the anthropology of death the Pacific region has been considered an ethnographic field of study in its own right. Robben rightly notes that Hertz's and van Gennep's comparisons have been generally accepted "but hardly anything as daring has been attempted since then" (2004: 13). The volume $O f$ Relations and the Death by Barraud et al. (1994) might be the exception. This comparison of four societies contains two Melanesian cases, but focuses on something given insufficient attention by Hertz, namely the exchanges involved in mortuary ritual. These are seen as a means to get at thought and values in the particular societies. Albeit the authors do not mention Hertz, one of them elsewhere (de Coppet, 1981) makes use of Hertz's insight into death as transitional process.

Around the time Hertz met with his untimely death while leading an attack on the enemy in World War I, Bronislaw Malinowski was getting a grasp of mortuary rites and exchange in the Trobriand Islands. Malinowski himself did not relate the two topics as much as did later anthropologists working in the Massim (Milne Bay Province, Papua New Guinea), an ethnographic field of study. In the introduction to the edited volume Death Rituals and Life in the Societies of the Kula Ring, Damon notes that for the contributions "the most important work follows from Hertz's famous essay on death" (1989: 14). Ritual change has taken place in the region. It counts as one of the reasons why the pattern discerned by Hertz is not explicitly dealt with in the contributions. That is a pity, because the wealth of data from within one region available for comparison here would make revisiting them from a Hertzian perspective a worthwhile endeavour. John Liep (this issue), who was involved in the debate, stresses the ongoing importance of mortuary exchanges in the Massim.

\section{Emotions and embodiment}

One aspect of general importance for which Hertz certainly deserves credit is his argument with regard to the way in which the emotions of the bereaved tend to be socially determined. Hertz (1960: 76) makes clear that the deceased's age, gender, social status, type of death, and so forth, matter concerning the social impact of the death. Henceforth it also influences how widespread and intense the emotions, if any are aroused at all, of the survivors will be.

In addition Hertz's model linking the period of mourning to the procedure of bodily decomposition and ideas about the journey of the soul strongly suggests a patterning of the bereaved's emotions over time. Psychiatrist Daniel Lagache has argued that Freud's writings on melancholy echo Hertz's essay. Pierre Lemonnier (this issue), who notices this, further explores the interrelation of the work of Freud and Hertz in addressing mortuary practices and related sentiments of the Ankave in Papua New Guinea.

Hertz's emphasis on " the collective representation of death," one could argue, connects it more strongly to Jungian notions of archetypes. And as far as the emotions are concerned, these are predominantly seen as social and not individual (let alone cultural, $c f$. Lutz, 1988) expressions. In this respect, according to Kan (1989: 14), "the legacy of Hertz is more an obstacle than an inspiration." On the other hand, as Davis (2000: 97-98) notes, Hertz was ahead of his time in paying a great deal of attention to what has become known today as embodiment.

Hertz acquired his understanding from literature study in the British Museum. He felt emotionally attached to the Dayak people he encountered in his readings (see Evans-Pritchard 1960: 10-11; Isnart 2006: 138). Had he not sacrificed his life for his beloved France at the early age of thirty-three, Hertz might have astonished us with further ground-breaking works that like the death essay would not have been past the expiry date even after a century. Let us now turn to the papers inspired by Hertz's essay, but focusing on mortuary rites in the Pacific region and based on field research.

\section{The papers}

This issue opens with Roger Lohmann's article 'Souvenir des morts : techniques de gestion 
de la mémoire dans un village de NouvelleGuinnée', considering how the Asabano handle material objects of the deceased. He distinguishes three strategies that survivors employ to create a memory of the relationship they once had with the dead as living persons or forget about it: curation, destroyal and gradual decay. Lohmann emphasizes people's agency in opting for one of these strategies, depending on what kind of memory or none whatsoever they want to retain.

Elisabetta Gnecchi-Ruscone's fine article 'Parallel journeys in Korafe women's laments (Oro Province, Papua New Guinea)' stresses the important role of women in death-related practices that underline the idea of homologous transitions found in Hertz's seminal essay. Here however the women by means of their laments and accompanying ritual gestures give symbolically birth to new ancestors. Both the deceased's body and spirit are thus transformed, the former in relics, whereas the survivors are supported in coming to terms with their grievous loss by the female work of social repair. Local Christian and magical practices intermingle with these activities.

Pierre Lemonnier brings together Hertz and Freud in his article, entitled 'Objets d'ambiguïté. Funérailles ankave (Papouasie NouvelleGuinée)'. Due to the overwhelming presence of "cannibal spirits" (ombo'), the Ankave-Anga of Papua New Guinea find it necessary to chase off the spirits of the recent dead. What is more, ambiguous objects reflect the deeply felt ambivalence towards the deceased in secondary funerals and more particularly in the work of mourning.

"The dead are looking at us". Food bowls as the dead in postfuneral wakes in Aorigi (Eastern Solomon Islands)', Sandra Revolon's article, is concerned with secondary funerals held once every five to ten years in the Solomon Islands. Revolon "explores the cognitive mechanisms involved in the transformation of subjects into objects". An object that stands central is a food bowl that together with its contents represents the deceased temporarily brought back to life in the context of the ritual. In gratitude for the inherited land and wealth the surviving descendants then perform a ceremonial wake analogous to the one held for the newly dead.

On Ambrym Island, Vanuatu, Knut Rio makes clear in his rich article 'Exposer la vie après la mort', a recreation of social relationships following a death takes place in ceremonial prestations of mostly perishable items. In great detail he outlines these exchanges (in the context of mortuary rites) of food, money and mats over a lengthy period of time. This "mobilization of material resources", according to Rio, enhances the transition of the deceased from the world of the living to the world of the dead.

Teri Sowell's contribution 'Spiritual remains: Applying Hertz to Hawai'i' considers how in eighteenth century Hawai' $i$ bones, teeth and hair of high-ranking chiefs were preserved and manipulated by ritual experts. These human artifacts became powerful relics, used for the purposes of worship and of communication with the spiritual world, including the deceased. The objects transmitted from generation to generation could gain more power than ordinary and even chiefly mortals, but all this changed when Hawai'ians adopted Christianity: the relics turned into "sentimental mementos".

Thomas Widlok, in his article 'The temporal dilemma of death', takes us to northwestern Australia. On the basis of ethnographic examples he seeks to show how the gradual ritual detachment of the deceased corresponds to the similar treatment of the dead person's belongings. "Property can be usefully considered to be the lasting objectification of memories", according to Widlok, and "enshrines the same dilemma of continuity and clarity that is posed by the dead body".

In his article 'On bone and flesh type of objects' Eric Venbrux is concerned with the practice of destroyal of the intimate possessions of the deceased in contrast to the practice of maintaining these objects as keepsakes, heirlooms or relics. Drawing on Hertz's essay and using ethnographic materials on the Tiwi from Bathurst and Melville Islands, in northern Australia, he focuses on the ritual use of objects of the dead and the production of metaphorical bodies for the dead (or better: disembodied spirits). Ritual actions with material objects of the deceased, he proposes, result in two distinctive types of objects that are either inalienable or serve as mediators between the living and the dead.

Finally, John Liep in his contribution 'Massim mortuary rituals revisited', argues that due to a plethora of exchanges, including marital exchange and exchanges of money and other valuables, mortuary rituals continue to be "the prime cultural focus of the Massim". This in spite of the demise of exhumation and secondary burial, the theme central to Hertz's essay, due to colonisation and missionisation. The ongoing importance of mortuary feasting in the region makes clear that the related exchanges still have a vital social and political function in 
Massim societies. Liep's revisit of the region of the Kula Ring, a follow-up of the comparative volume mentioned earlier, concludes this issue.

Death rites convey people's most important values and the basic assumptions of their worldview, including their notions of self, power, and destiny (Metcalf \& Huntington, 1991). Moreover, death practices address the senses and mobilize material objects allowing for an immediacy and intimacy that cannot be had in another way. Commensality with the dead is a phenomenon predicated on the entanglement of spiritual values with material culture, which stands central in this special issue on change in funerary culture in Oceania.

\section{BIBLIOGRAPHY}

BARLEY Nigel, 1995. Dancing on the Grave: Encounters with Death, London, John Murray.

Barraud Cécile, Daniel de Coppet, André Iteanu \& Raymond JAmous, 1994. Of Relations and the Dead: Four Societies Viewed from the Angle of Their Exchanges, Oxford, Berg.

BLOCH Maurice and Jonathan PARRY (eds), 1982. Death and the Regeneration of Life, Cambridge, Cambridge University Press.

DAMON Frederick H., 1989. Introduction, in F.H. Damon and R. Wagner (eds), Death Rituals and Life in the Societies of the Kula Ring, DeKalb, Northern Illinois University Press, pp. 3-19.

DAvies Douglas J., 2000. Robert Hertz: The social thriumph over death, Mortality 5, 1, pp. 97-102.

De Coppet Daniel, 1981. The Life-Giving Death, in H.C. Humphreys and H.C. King (eds), Mortality and Immortality: The Anthropology and Archaeology of Death, London, Academic Press, pp. 175204.

Evans-Pritchard Edward, 1960. Introduction, in R. Hertz, Death and the Right Hand, Glencoe, IL, The Free Press, pp. 9-24.

-, 1981. A History of Anthropological Thought, London, Faber and Faber.

Hallam Elizabeth and Jenny Hockey, 2001. Death, Memory and Material Culture, Oxford, Berg.
Hertz Robert, 1960[1907]. A Contribution to the Study of the Collective Representation of Death, in Death and the Right Hand, Translated by R. and C. Needham, Glencoe, IL, The Free Press, pp. 27-86 et pp. 117-154.

IsNART Cyril, 2006. "Savages Who Speak French": Folklore, Primitivism and Morals in Robert Hertz, History and Anthropology 17, 2, pp. 135-152.

KAN Sergei, 1989. Symbolic Immortality: The Tlingit Potlatch of the Nineteenth Century, Washington, D.C., Smithsonian Institution Press.

Lutz Catherine A., 1988. Unnatural Emotions: Everyday Sentiments on a Micronesian Atoll and Their Challenge to Western Theory, Chicago, The University of Chicago Press.

Масно Thomas, 1998. Der zweite Tod. Zur Logik doppelter Bestattungen, Paragrana: Internationale Zeitschrift für Historische Anthropologie 7, 2, pp. 43-60.

Metcalf Peter, 1982. A Borneo Journey into Death: Berewan Eschatology from Its Rituals, Philadelphia, University of Pennsylvania Press.

Metcalf Peter and Richard Huntington, 1991. Celebrations of Death: The Anthropology of Mortuary Ritual, Second Edition, Cambridge, Cambridge University Press.

NeEDham Rodney, 1979. Robert Hertz, in David L. Stills (ed.), International Encyclopedia of the Social Sciences, vol. 18, Biographical Supplement, New York, The Free Press, pp. 295-297.

Palgi Phyllis and Henry Abramovitch, 1984. Death: A Cross-Cultural Perspective, Annual Review of Anthropology 13, pp. 385-417.

PARKIN Robert, 1996. The Dark Side of Humanity: The Work of Robert Hertz and its Legacy, Amsterdam, Harwood Academic.

Pouwer Jan, 1961. New Guinea as a field for ethnological study: A preliminary analysis, Bijdragen tot de Taal-, Land-en Volkenkunde 117, 1, pp. 1-24.

RobBEN Antonius C.G.M., 2004. Death and Anthropology: An Introduction, in Antonius C.G.M. Robben (ed.), Death, Mourning and Burial: A CrossCultural Reader, Oxford, Blackwell, pp. 1-16.

Seremetakis C. Nadia, 1991. The Last Word: Women, Death, and Divination in Inner Mani, Chicago, University of Chicago Press.

Suzuki Hikaru, 2000. The Price of Death: The Funeral Industry in Contemporary Japan, Stanford, Stanford University Press.

VAN BAAL Jan, 1971. Symbols for Communication. Assen, Van Gorcum. 